\title{
Will Electric Vehicles Be Killed (again) or Are They the Next Mobility Killer App?
}

\author{
Christian Thiel ${ }^{*}(\mathbb{D}$, Anastasios Tsakalidis $(\mathbb{D}$ and Arnulf Jäger-Waldau( 1 \\ European Commission, Joint Research Centre (JRC), 21027 Ispra, Italy; anastasios.tsakalidis@ec.europa.eu (A.T.); \\ arnulf.jaeger-waldau@ec.europa.eu (A.J.-W.) \\ * Correspondence: christian.thiel@ec.europa.eu; Tel.: +39-0332-78-9207
}

Received: 11 March 2020; Accepted: 7 April 2020; Published: 10 April 2020

\begin{abstract}
Electric vehicles (EVs) have been around for more than a hundred years. Nevertheless, their deployment has not been a sustainable success up until now. Many scientists, engineers and policymakers argue that EVs are a promising, maybe even indispensable option to achieve ambitious decarbonization goals, if powered by electricity from renewable energy sources. At the moment, the EVs market is gaining a lot of momentum and we may be near the point of no return for a sustained mass market deployment of electric vehicles. Many papers exist that describe future prospects of EVs. In our commentary we try to provide a bigger picture view and look at market and societal aspects. We analyze why previous generations of EVs were not successful and how current electric vehicles could become a sustainable success. We perform a semi-quantitative Strengths, Weaknesses, Opportunities, Threats (SWOT) analysis and find that current electric vehicle designs are technologically on par with or better than conventional alternatives. Car buyers go electric when the economics make sense to them. We conclude that incentives are needed for electric vehicles until battery costs lower-as much as to allow EVs to become cheaper-from a total cost of ownership (TCO) perspective, than other alternatives. Other policy measures are needed to overcome remaining barriers, especially in supporting the setup and operation of publicly accessible recharging points to overcome range anxiety. EVs in isolation may not be the next mobility killer app. The real next mobility killer app may emerge as an autonomous shared EV in a world where the border between public and private transport will cease to exist. The findings of our commentary are relevant for scientists, policymakers and industry.
\end{abstract}

Keywords: transport electrification; electric vehicles; policy measures; incentives; transport policy; energy policy

\section{Introduction}

120 years ago, when cars emerged on the road in larger numbers, electric vehicles (EVs) (With a focus on battery electric vehicles.) were among the leaders in the transition from horse-drawn carriages and other transport modes to cars. While they were market leaders around 1900, their share soon declined and they were replaced by, at the time, a better alternative: internal combustion engine vehicles (ICEVs). During the past 100 years, not a lot happened regarding EVs. There were a few attempts to gain ground, accompanied by optimistic forecasts, but they did not lead to a sustained resurrection of EVs. One author described this phenomenon as the eternal emergence of the electric car [1]. In the film "Who killed the electric car?" Chris Paine argues that newly launched EVs in the 1990s were the better alternative over ICEVs, but were stopped by a conspiracy of incumbent car manufacturers and government officials [2].

Recently, EVs are gaining momentum again. They are seen by many as a key enabler to reach the global long-term climate goals [3]. Optimistic forecasts for the future market evolution of EVs are 
outrivaling each other [4]. Will EVs deliver this time? We present what needs to happen, to our view, for EVs to achieve a sustained market growth. Consequently, we present in our commentary a bigger picture view on the opportunities and challenges for EVs. This may be relevant to many scientists, policymakers and decision-makers from industry working on EVs.

\section{One Hundred and Twenty Years of EV Re-emergence}

After the decline of the first EVs in the early 1900s consumers and industry lost interest in this technology up until the first oil crisis, when attention in EVs increased again. Over the following years several new EVs with futuristic designs hit the roads. The Zagato Zele-marketed in North America under the programmatic name Elcar 2000-and the Sebring-Vanguard Citicar entered the market in the early 1970s. These cars and other EVs featured some technology compromises, which led to consumer dissatisfaction (see Box 1) [5].

Box 1. Example of technology compromises in EVs of the 1970s [5].

"The Elcar has no fresh-air ventilation system. Even with the windows open, the car was hot and stuffy in the summer. The Elcar also lacks a heater or defroster, perhaps a concession to the fact that cold weather makes the car's range impractically short anyway. In its petition for exemption from Federal safety standards, the manufacturer of the Elcar claimed that the sliding windows would alleviate fogging - but that proved true only when the car was moving."

The GM EV1, Th!nk City and Peugeot 106 Electric achieved higher technological sophistication. The market entry of these and similar EVs as well as the zero-emission vehicle program of California led to projections of fast and high EV deployment.

Despite rather high expectations from various researchers on the future evolution of EVs (see Box 2 and Figure 1), none of the EVs that entered the market between 1900 and 2010 became a sustainable commercial success.

Box 2. Example of high EV expectations in the 1980s [6].

"To achieve commercial success, the battery vehicle must meet the operators' performance requirements in full and must do so at a total cost of lifetime ownership which is competitive with the equivalent gasoline or diesel-powered vehicle. A demonstration program involving 71 electric vans and buses, known as Dodge Silent Karriers, is now well established and some results are presented. Following the satisfactory performance in service and the favorable operator reaction to these vehicles, an improved vehicle, the Dodge ' 50 Series', is to go into production in October 1981 at a rate of up to 20 per month. A whole life ownership cost comparison with the diesel vehicle shows that at present Government support is needed equivalent to about $14 \%$ of the total lifetime cost in order to achieve parity. The subsidy requirement is expected to reduce to zero by 1987."

\section{When the Economics Make Sense to Car Drivers, They Go Electric}

From 2010 onwards a new generation of EVs were deployed. Among the first and most successful ones are the Tesla Roadster, Nissan Leaf, Mitsubishi I-Miev and its European siblings, the Citroen C-Zero and Peugeot Ion. Different from previous EV generations, which mainly used lead-acid, nickel-cadmium or nickel-metal-hydride batteries, the new EVs after 2010 used lithium-ion batteries with a better technical performance [7]. The massive investments of the industry in mobile lithium-ion battery research, development and production has led to an unprecedented cost reduction [8]. EVs also benefited from steady improvements and cheaper processors, which are vital components for the battery management systems, power electronics and many other vehicle systems [9]. Still, in most countries the purchase cost and total cost of ownership (TCO) for EVs are much higher than the ones of comparable conventional cars [10]. 


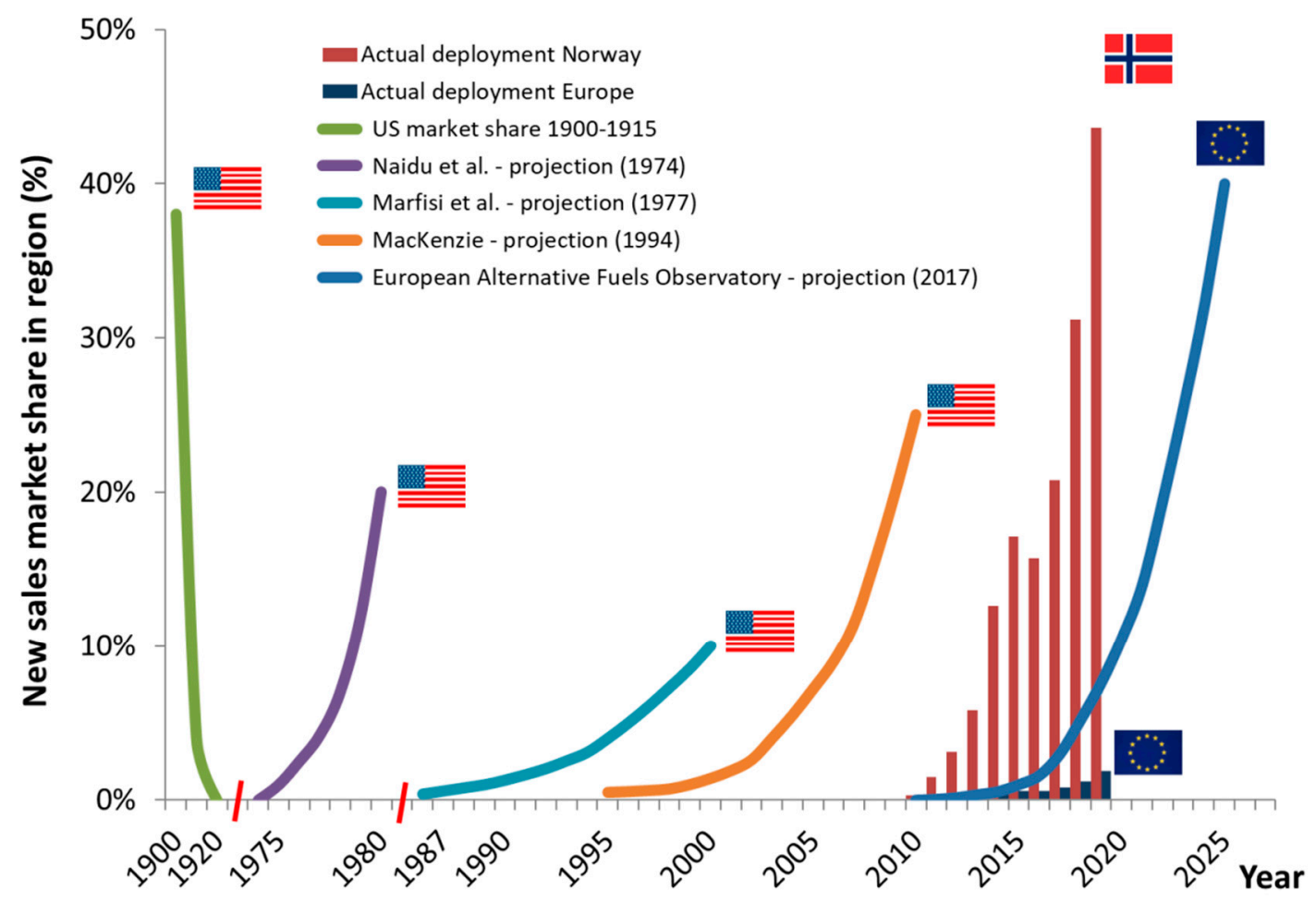

Figure 1. Electric vehicle sales evolution and projections in various countries and regions from 1900 to 2025. Timeline not to scale. Europe includes the group of 28 European Union Member States (EU28) plus Iceland, Norway, Switzerland and Turkey. The 2019 sales data are January-July. Adapted from Fréry [1] with recent sales data from European Alternative Fuels Observatory [11].

Nevertheless, Figure 1 reveals that, while experts still see battery performance as a possible barrier and researchers continue to strive for battery improvements [12], consumers already go electric in those countries where market barriers are removed by government support measures, such as Norway, which is a global leading country in terms of EV shares. Interestingly, while Norway has been offering substantial incentives to prospective EV buyers since 1990, consumers only began to take up the incentives from 2010 onwards [13]. Subsequently, within ten years EVs morphed from a niche offer to the mainstream choice in Norway. It should be mentioned that already in 2016 Norwegian politicians agreed to phase out ICEVs by 2025. The national transport plan 2018-2029 states that this goal will be achieved by «technological maturity in the vehicle segments» [14]. The Norwegian experience suggests that EVs are seen by most consumers as the best alternative when the economics are favorable. In fact, while EVs benefit from tax exemptions, conventional vehicles are taxed so high in Norway that retail prices for many EVs are lower than for comparable ICEVs [13].

Meanwhile, a recent study [15] on the impact incentive policies and other socio-economic factors have on the adoption of EVs, found that even with the abolishment of subsidy schemes, there are other, potentially more effective policy solutions for promoting EVs. These are based on a series of factors that would have a positive and high significance in predicting the adoption of EVs, such as road priority, charging infrastructure density and fuel prices. The development of new business models for encouraging the uptake of EVs in the absence of policy support has also been investigated [16].

Table 1 presents a semi-qualitative analysis of the strengths, weaknesses, opportunities and threats related to EVs that were identified in the relevant literature, ordered by number of instances. We have identified altogether 8 strengths, 10 weaknesses, 10 opportunities and 7 threats. They cover a mix of market, technical and societal aspects. Market and market imperfection related aspects feature among the highest mentioned strengths, weaknesses, opportunities and threats in the literature that we analyzed. 
Table 1. Strengths, weaknesses, opportunities and threats related to EVs found in the literature.

\begin{tabular}{|c|c|c|}
\hline & Type & Source \\
\hline \multirow{8}{*}{ Strengths } & Positive market response to targeted support measures & {$[13,15,17-20]$} \\
\hline & Zero tailpipe emissions & [21-23] \\
\hline & Low operational noise levels & [24-26] \\
\hline & Local air quality benefits & {$[21,22]$} \\
\hline & Low operational costs & {$[10,22]$} \\
\hline & No fossil fuel use & {$[22,23]$} \\
\hline & Improved driving experience & {$[27,28]$} \\
\hline & Positive public image & {$[27,29]$} \\
\hline \multirow{10}{*}{ Weaknesses } & High sticker prices for EVs & {$[10,13,19,21,22,30]$} \\
\hline & Shorter range and long recharging time & {$[19,21,30,31]$} \\
\hline & Lack of sufficient charging infrastructure and harmonized standards & {$[15,21-23]$} \\
\hline & Grid restrictions & {$[22,23,32]$} \\
\hline & High battery prices & {$[12,21,22]$} \\
\hline & Limited model choice and after sales support & {$[25,33]$} \\
\hline & Higher emissions in EV and power production & {$[21,23]$} \\
\hline & Lower range real life vs certified & [34] \\
\hline & Low consumer knowledge of EVs and associated incentives & [17] \\
\hline & Gap between EV stated preference and actual adoption trends & {$[30]$} \\
\hline \multirow{10}{*}{ Opportunities } & Increase user/public awareness on incentives and new technology & {$[17,19,20,22,27,30]$} \\
\hline & $\begin{array}{l}\text { Privileged access to lanes and low-emission zone, free parking } \\
\text { and charging }\end{array}$ & {$[13,15,17,22,23]$} \\
\hline & Development of innovative business models & {$[16,22,23,35]$} \\
\hline & Can increase energy security & {$[19,22,23,32]$} \\
\hline & $\begin{array}{l}\text { Vehicle-to-Grid and to-Home, synergies with variable renewable } \\
\text { energy sources }\end{array}$ & {$[19,22,32]$} \\
\hline & $\begin{array}{l}\text { With the right policy mix, EVs can accelerate the decarbonization of } \\
\text { the power sector }\end{array}$ & {$[21,23,32]$} \\
\hline & Development of alternative battery and cell technologies & {$[12,22,23]$} \\
\hline & Good option to decarbonize transport & {$[23,32]$} \\
\hline & Future ICEV bans in countries and cities & {$[36,37]$} \\
\hline & New models cheaper and with longer ranges & [25] \\
\hline \multirow{7}{*}{ Threats } & Consumer misperceptions of EVs & {$[19,22,30]$} \\
\hline & Raw material constraints and spikes in commodity prices & {$[12,22,23]$} \\
\hline & Better other low/zero-emission mobility options & {$[21,23]$} \\
\hline & Low oil and increasing electricity prices & [15] \\
\hline & Safety incidents & [23] \\
\hline & Child labor and health/safety issues in some mines (e.g., cobalt) & [12] \\
\hline & $\begin{array}{l}\text { Use-based incentives to car users gives a message favoring car } \\
\text { use(decreased marginal cost may cause rebound effects) }\end{array}$ & [20] \\
\hline
\end{tabular}

On the basis of Table 1, the Strengths, Weaknesses, Opportunities, Threats (SWOT) analysis in Figure 2 was developed. It shows the most important strengths, weaknesses, opportunities and threats 
that modern EVs have, from a consumer perspective and societal point of view, which should be taken into consideration when developing policies related to road transport electrification. A series of mitigation policies introduced at European and global level are provided as a means to address weaknesses and threats.

The most important strengths of today's EVs for consumers are driving comfort and lower operational costs as well as a positive environmental image. From a societal perspective, the most important strengths are the EVs' potential to reduce fossil oil use, the absence of tailpipe emissions and related air quality benefits [38,39]. This clearly sets them apart from plug-in hybrid electric vehicles (PHEVs) that are a low emission alternative but still cause tailpipe emissions. Nevertheless, PHEVs could be threat to the market success of EVs.

Opportunities for a further EV market growth are the trend to increased electric ranges and lower purchase costs with new model generations [10,40]. Privileged access to commuter lanes, low-emission zones, free parking and charging can offer substantial benefits for EV drivers [13].

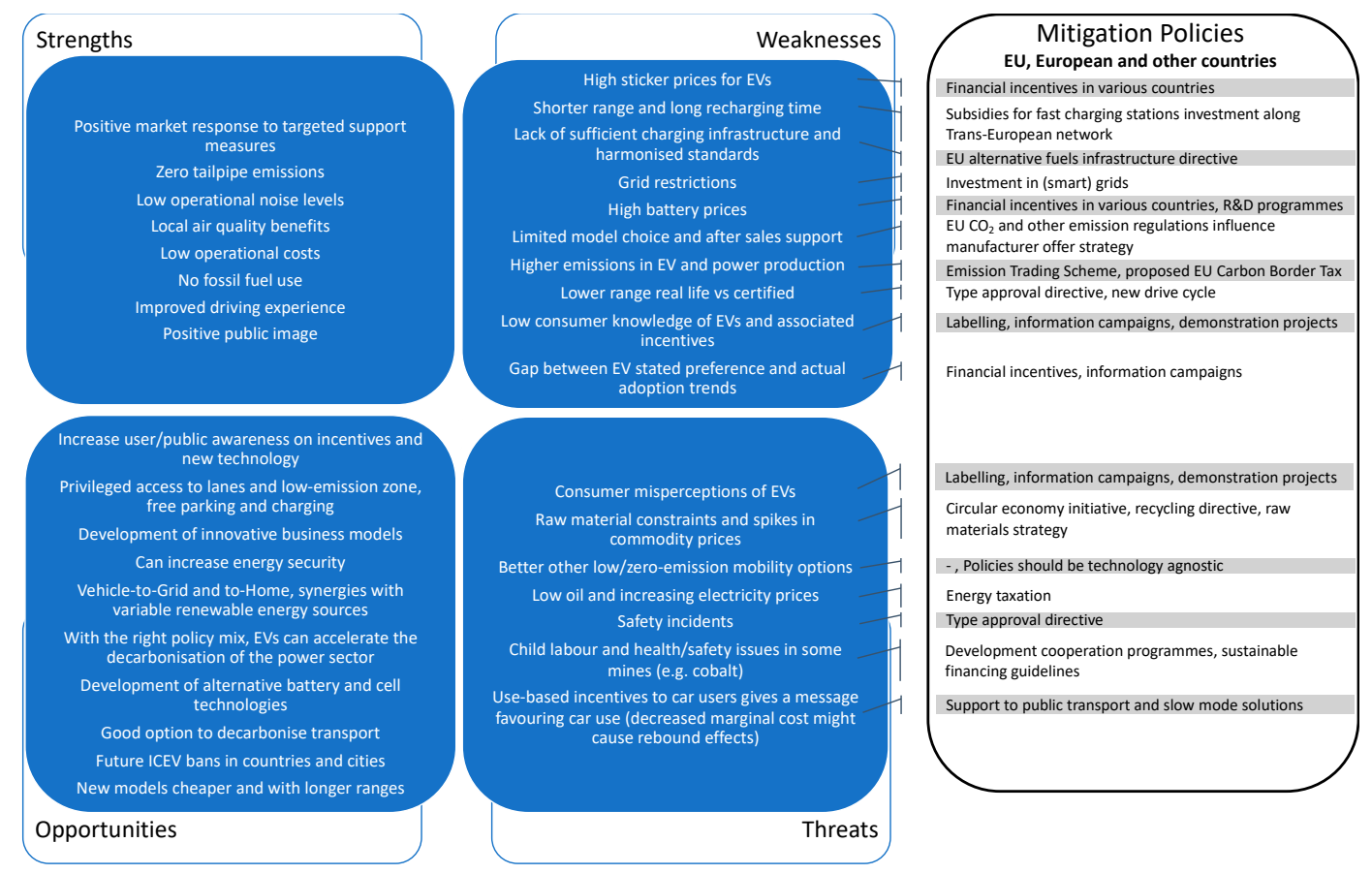

Figure 2. Strengths, Weaknesses, Opportunities, Threats (SWOT) analysis of electric vehicles (EVs) vs. internal combustion engine vehicles (ICEVs) and support policies mitigating the weaknesses and threats, adapted from [41].

Possible future bans of ICEVs in countries or cities bear significant upside potential for the future sales of EVs [36]. With the right policy mix, EVs can accelerate the decarbonization of the power sector [42]. EVs can facilitate the grid integration of higher variable renewable energy sources [32]. However, besides high costs, several other weaknesses and threats remain before EVs can develop into a full-scale and sustainable market success.

\section{How Can Electric Vehicles Become a Sustainable Success?}

EVs will need to contain their threats, overcome their weaknesses, exploit their strengths and transform their opportunities into tangible advantages. For most of the weaknesses and threats, policy support measures can mitigate their impact. Some of the EV opportunities are linked to national, regional or municipal policies. The European Union (EU) and European countries as well as other states (e.g., China, United States) have a wide portfolio of policy support measures in place to foster low-emission mobility [40]. These improve the competitive positioning of EVs (see Figure 2). 
Recent initiatives in the EU have already helped to address some of the weaknesses of EVs, notably (i) the lack of harmonized standards and insufficient charging infrastructure, which remains a major concern for EV and other car drivers [43,44], through the EU directive for alternative fuels infrastructure and the investment subsidies for the deployment of recharging network along major European motorways [39] and (ii) the gap between real-life and certified electric range [45] through the new drive cycle, the worldwide harmonized light vehicles test procedure as mandated in the EU type approval procedure [34].

The European Commission is committed to put the EU on a clear path in becoming the world's first climate-neutral continent [46]. Several newly proposed initiatives aim at creating a more favorable market environment for EVs. The plan to cut in half greenhouse gas emissions in the EU by 2030, an increased ambition from the current plan of $40 \%$ reductions, can accelerate the deployment of EVs and decarbonization of the power sector. Related emission regulations for cars influence the offer strategies of car manufacturers and increase model choice for car buyers [47]. Low oil-derived fuel prices remain a threat to the success of EVs, as Germany demonstrates, where gasoline and diesel pump prices rose roughly $18 \%$ since 2005 [48], while domestic consumer retail prices for electricity grew by $67 \%$ [49]. The review of the EU energy taxation directive could help improving the TCO position of EVs.

Within the TCO, the purchase price and depreciation costs are still dominant for EVs $[10,50]$. A key improvement needs to come from reducing the costs of batteries. Financial incentives can help to kickstart the market in the beginning. Then, the market has to take over to achieve significant cost reductions so that incentives can gradually be phased out. The withdrawal of policy support measures needs to be carefully designed. If it happens too early or too abruptly, it can lead to the collapse or perturbations of EV sales. Figure 3 shows as an example the recent developments of EV sales in Denmark and Estonia, where the suspension of financial incentives resulted in drastic reductions of EV sales. The reintroduction of incentives in Denmark has helped its EV market to recover. In Estonia, no further incentives were introduced after 2014 and consequently the EV market stayed low in this country. These examples show how reliant the EV market still is on policy support measures.

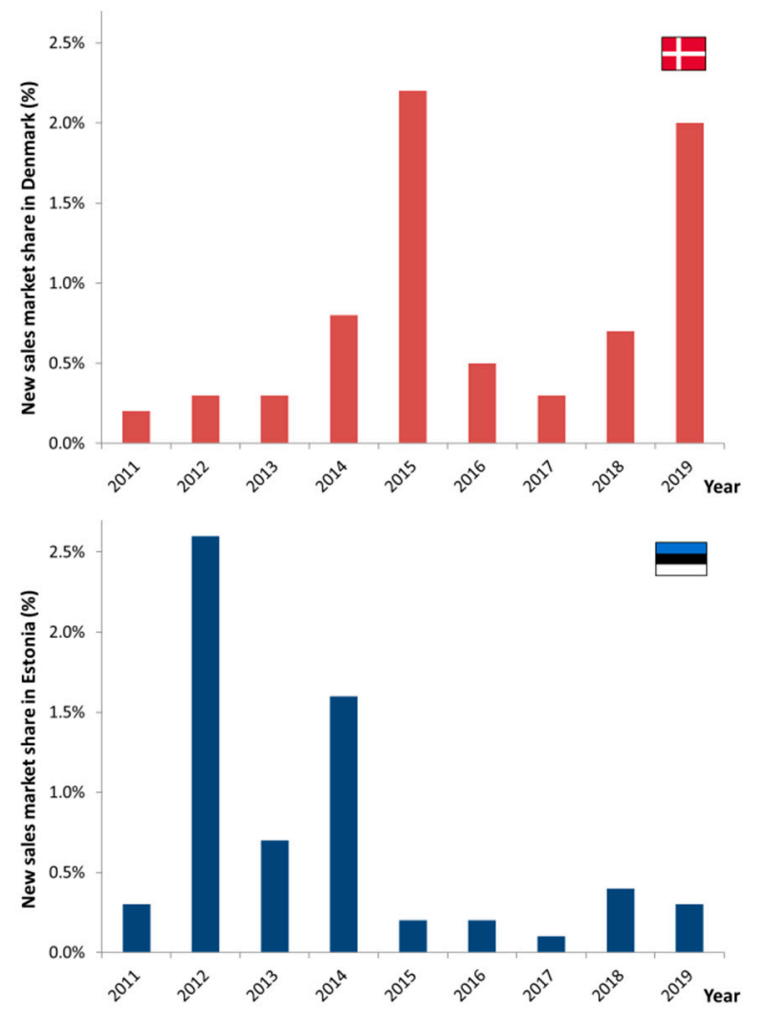

Figure 3. Electric vehicle market shares in Denmark and Estonia from 2011 to 2019. 2019 sales data are January-July. Data from European Alternative Fuels Observatory [7]. 
Furthermore, policies can assist in overcoming other limitations and mitigate or prevent any undesired effects that may arise from a larger deployment of EVs. An EU carbon border tax could ensure a further reduction of emissions in the supply chain for EVs, including battery production. This tax would complement the emission trading scheme, designed to ensure that additional power demand from EVs is satisfied in a carbon neutral way [42]. The EU circular economy initiative aims at mitigating the effect of raw material constraints [51]. Development cooperation programs and sustainable financing guidelines [52] aim at preventing child labor and health/safety issues, as reported in connection with some mining activities of raw materials used for EVs.

\section{Policy Implications}

Unless they receive incentives, EVs are still more expensive than ICEVs, not only in terms of purchase price but also from a TCO perspective. In countries where incentives are substantial, EVs have become a mainstream option for car buyers. Incentives should target zero emission mobility solutions and need to remain in place until EVs or other zero emission solutions, reach cost parity with ICEVs. Otherwise, the deployment of zero emission mobility could stop. Additionally, the carbon content of fuels will likely have to be taxed higher in order to ensure that zero emission vehicles realize necessary cost savings during the use phase versus ICEVs. Policy support measures for an appropriate and publicly accessible recharging network can further increase the confidence of potential EV drivers in the viability of EVs. These policies need to be accompanied by additional support measures in order to overcome remaining barriers and avoid or mitigate undesired effects. The EU has a rather comprehensive policy package in place and intends to complement it further, but a lot depends on policies that are in the jurisdiction of the EU member states and other authorities. It will be crucial to tailor policy measures thoroughly so that a zero emission mobility becomes a reality, at least for cars. Lack of appropriate policies could lead to a situation in which EV deployment and related progress is "killed". Similar policy related conclusions have been identified by other authors for the deployment of zero emission vehicles in various regions of the world [53-55]. Besides EVs, there are other zero emission mobility solutions such as walking and cycling for short distances and fuel cell cars as well as electric or fuel cell trams, buses, trains etc. for longer distances. For some of these alternatives more efforts and a smart integration of different modes may be required to make them as convenient for consumers as cars.

\section{Conclusions}

EVs have the potential to become an important pillar for reaching a long-term climate neutral society. After roughly 120 years-during which EVs failed to achieve a sustained market success-EVs are now technologically sophisticated enough to compete with conventional alternatives. However, also today EVs still need support measures in order to be a fully viable market proposition for prospective car buyers. EVs in isolation may not be the next mobility killer app able to completely transform the mobility system into one that is more sustainable, more affordable and more convenient than the current one. The real next mobility killer app may emerge as an autonomous shared EV in a world where the border between public and private transport will cease to exist. In any case competitive EVs would be a prerequisite for this. More research is needed to fully understand the implications of autonomous shared EVs [56], their relation to advancements in telecommunications [57] and the electromagnetic compatibility of EVs with the sensors, actuators and communication devices of autonomous vehicles [58,59].

Author Contributions: All authors (C.T., A.T. and A.J.-W.) contributed to the conceptualization, writing and review of the paper. All authors have read and agreed to the published version of the manuscript.

Funding: This research received no external funding.

Acknowledgments: The views expressed here are purely those of the authors and may not, under any circumstances, be regarded as an official position of the European Commission. The authors would like to thank Barbara Realini for proofreading the manuscript and for her linguistic improvements of the manuscript. 
Conflicts of Interest: The authors declare no conflict of interest.

\section{Glossary}

$\begin{array}{ll}\mathrm{CO}_{2} & \text { Carbon Dioxide } \\ \mathrm{EU} & \text { European Union } \\ \text { EU28 } & \text { Group of 28 European Union Member States } \\ \mathrm{EV} & \text { Electric Vehicle } \\ \mathrm{ICEV} & \text { Internal Combustion Engine Vehicles } \\ \text { PHEV } & \text { Plug-in Hybrid Electric Vehicle } \\ \text { R\&D } & \text { Research and Development } \\ \text { SWOT } & \text { Strengths, Weaknesses, Opportunities, Threats } \\ \text { TCO } & \text { Total Cost of Ownership } \\ \text { US } & \text { United States }\end{array}$

\section{References}

1. Fréry, F. Un cas d'amnésie stratégique-l'éternelle émergence de la voiture électrique. In Proceedings of the IXème Conférence Internationale de Management Stratégique Montpellier, Montpellier, France, 24-26 May 2000.

2. Paine, C. Who Killed the Electric Car? Available online: https://www.youtube.com/watch?v=r75lqbA0uMM\& list=PL61382C9E67BA0781\&index=9 (accessed on 4 January 2020).

3. Clean Energy Ministerial EV30@30 campaign-Factsheet, June 2019. Available online: http://www. cleanenergyministerial.org/sites/default/files/2019-06/EV30\%4030factsheet\%28June2019\%29.pdf (accessed on 4 January 2020).

4. Tsakalidis, A.; Thiel, C. Electric Vehicles in Europe from 2010 to 2017: Is Full-Scale Commercialisation Beginning? Publications Office of the European Union: Luxembourg, 2018; ISBN 978-92-79-96719-1. [CrossRef]

5. Consumers Union Inc. Consumer Reports; Consumers Union Inc.: Mount Vernon, NY, USA, 1975.

6. Edwards, B.D. Creating the Traffic-Compatible Electric Vehicle Industry in the UK-The Chloride Approach; SAE International: Warrendale, PA, USA, 1981. [CrossRef]

7. Editorial. Reality check. Nat. Energy 2018, 3, 245. [CrossRef]

8. Nykvist, B.; Nilsson, M. Rapidly falling costs of battery packs for electric vehicles. Nat. Clim. Chang. 2015, 5, 329-332. [CrossRef]

9. Seba, T. Clean Disruption-Why Energy \& Transportation will be Obsolete by 2030, Swedbank Nordic Energy Summit 2016, Oslo, Norway. Available online: https://www.youtube.com/watch?v=Kxryv2XrnqM (accessed on 21 October 2019).

10. Lévay, P.Z.; Drossinos, Y.; Thiel, C. The effect of fiscal incentives on market penetration of electric vehicles: A pairwise comparison of total cost of ownership. Energy Policy 2017, 105, 524-533. [CrossRef]

11. European Alternative Fuels Observatory Passenger electric car sales \& Zero emission vehicles fleet study (November 2017). Available online: www.eafo.eu (accessed on 21 October 2019).

12. Turcheniuk, K.; Bondarev, D.; Singhal, V.; Yushin, G. Ten years left to redesign lithium-ion batteries. Nature 2018, 559, 467-470. [CrossRef] [PubMed]

13. Figenbaum, E. Perspectives on Norway's supercharged electric vehicle policy. Environ. Innov. Soc. Transit. 2017, 25, 14-34. [CrossRef]

14. Government of Norway. Meld. St. 33 (2016-2017), National Transport Plan 2018-2029; Government of Norway: Oslo, Norway, 2017.

15. Wang, N.; Tang, L.; Pan, H. A global comparison and assessment of incentive policy on electric vehicle promotion. Sustain. Cities Soc. 2019, 44, 597-603. [CrossRef]

16. Nian, V.; Hari, M.P.; Yuan, J. A new business model for encouraging the adoption of electric vehicles in the absence of policy support. Appl. Energy 2019, 235, 1106-1117. [CrossRef]

17. Jenn, A.; Springel, K.; Gopal, A.R. Effectiveness of electric vehicle incentives in the United States. Energy Policy 2018, 119, 349-356. [CrossRef]

18. Tsakalidis, A.; Julea, A.; Thiel, C. The Role of Infrastructure for Electric Passenger Car Uptake in Europe. Energies 2019, 12, 4348. [CrossRef] 
19. Cansino, J.M.; Sánchez-Braza, A.; Sanz-Díaz, T. Policy instruments to promote electro-mobility in the EU28: A comprehensive review. Sustainability 2018, 10, 2507. [CrossRef]

20. Langbroek, J.H.M.; Franklin, J.P.; Susilo, Y.O. The effect of policy incentives on electric vehicle adoption. Energy Policy 2016, 94, 94-103. [CrossRef]

21. Abdul-Manan, A.F.N. Uncertainty and differences in GHG emissions between electric and conventional gasoline vehicles with implications for transport policy making. Energy Policy 2015, 87, 1-7. [CrossRef]

22. Mahmoudzadeh Andwari, A.; Pesiridis, A.; Rajoo, S.; Martinez-Botas, R.; Esfahanian, V. A review of Battery Electric Vehicle technology and readiness levels. Renew. Sustain. Energy Rev. 2017, 78, 414-430. [CrossRef]

23. Tran, M.; Banister, D.; Bishop, J.D.K.; McCulloch, M.D. Realizing the electric-vehicle revolution. Nat. Clim. Chang. 2012, 2, 328-333. [CrossRef]

24. Campello-Vicente, H.; Peral-Orts, R.; Campillo-Davo, N.; Velasco-Sanchez, E. The effect of electric vehicles on urban noise maps. Appl. Acoust. 2017, 116, 59-64. [CrossRef]

25. Figenbaum, E.; Assum, T.; Kolbenstvedt, M. Electromobility in Norway: Experiences and Opportunities. Res. Transp. Econ. 2015, 50, 29-38. [CrossRef]

26. Haddadian, G.; Khodayar, M.; Shahidehpour, M. Accelerating the Global Adoption of Electric Vehicles: Barriers and Drivers. Electr. J. 2015, 28, 53-68. [CrossRef]

27. Ullah, A.; Aimin, W.; Ahmed, M. Smart automation, customer experience and customer engagement in electric vehicles. Sustainability 2018, 10, 1350. [CrossRef]

28. Skippon, S.M.; Kinnear, N.; Lloyd, L.; Stannard, J. How experience of use influences mass-market drivers' willingness to consider a battery electric vehicle: A randomised controlled trial. Transp. Res. Part A Policy Pract. 2016, 92, 26-42. [CrossRef]

29. Burgess, M.; King, N.; Harris, M.; Lewis, E. Electric vehicle drivers' reported interactions with the public: Driving stereotype change? Transp. Res. Part F Traffic Psychol. Behav. 2013, 17, 33-44. [CrossRef]

30. Coffman, M.; Bernstein, P.; Wee, S. Electric vehicles revisited: A review of factors that affect adoption. Transp. Rev. 2017, 37, 79-93. [CrossRef]

31. Franke, T.; Rauh, N.; Günther, M.; Trantow, M.; Krems, J.F. Which Factors Can Protect Against Range Stress in Everyday Usage of Battery Electric Vehicles? Toward Enhancing Sustainability of Electric Mobility Systems. Hum. Factors 2016, 58, 13-26. [CrossRef] [PubMed]

32. Seddig, K.; Jochem, P.; Fichtner, W. Integrating renewable energy sources by electric vehicle fleets under uncertainty. Energy 2017, 141, 2145-2153. [CrossRef]

33. Dombrowski, U.; Engel, C. Impact of electric mobility on the after sales service in the automotive industry. Procedia CIRP 2014, 16, 152-157. [CrossRef]

34. Pavlovic, J.; Tansini, A.; Fontaras, G.; Ciuffo, B.; Garcia Otura, M.; Trentadue, G.; Suarez Bertoa, R.; Millo, F. The Impact of WLTP on the Official Fuel Consumption and Electric Range of Plug-in Hybrid Electric Vehicles in Europe; SAE International: Warrendale, PA, USA, 2017; pp. 1-10. [CrossRef]

35. Bohnsack, R.; Pinkse, J.; Kolk, A. Business models for sustainable technologies: Exploring business model evolution in the case of electric vehicles. Res. Policy 2014, 43, 284-300. [CrossRef]

36. Plötz, P.; Axsen, J.; Funke, S.A.; Gnann, T. Designing car bans for sustainable transportation. Nat. Sustain. 2019, 2, 534-536. [CrossRef]

37. Meckling, J.; Nahm, J. The politics of technology bans: Industrial policy competition and green goals for the auto industry. Energy Policy 2019, 126, 470-479. [CrossRef]

38. Jochem, P.; Doll, C.; Fichtner, W. External costs of electric vehicles. Transp. Res. Part D Transp. Environ. 2016, 42, 60-76. [CrossRef]

39. Thiel, C.; Julea, A.; Acosta Iborra, B.; De Miguel Echevarria, N.; Peduzzi, E.; Pisoni, E.; Gómez Vilchez, J.J.; Krause, J. Assessing the Impacts of Electric Vehicle Recharging Infrastructure Deployment Efforts in the European Union. Energies 2019, 12, 2409. [CrossRef]

40. IEA. Global EV Outlook 2018; IEA: Paris, France, 2018; ISBN 9789264302365.

41. Quak, H.; Nesterova, N.; Van Rooijen, T. Possibilities and Barriers for Using Electric-powered Vehicles in City Logistics Practice. Transp. Res. Procedia 2016, 12, 157-169. [CrossRef]

42. Thiel, C.; Nijs, W.; Simoes, S.; Schmidt, J.; van Zyl, A.; Schmid, E. The impact of the EU car CO2 regulation on the energy system and the role of electro-mobility to achieve transport decarbonisation. Energy Policy 2016, 96, 153-166. [CrossRef] 
43. Figenbaum, E.; Kolbenstvedt, M. Norwegian user and usage profiles for BEVs and PHEVs -Results from a Norwegian survey of vehicle owners. In Proceedings of the 30th International Electric Vehicle Symposium (EVS30), Stuttgart, Germany, 9-11 October 2017; pp. 1084-1101.

44. Kühl, N.; Goutier, M.; Ensslen, A.; Jochem, P. Literature vs. Twitter: Empirical insights on customer needs in e-mobility. J. Clean. Prod. 2019, 213, 508-520. [CrossRef]

45. Donati, A.V.; Dilara, P.; Thiel, C.; Spadaro, A.; Gkatzoflias, D.; Drossinos, Y. Individual Mobility: From Conventional to Electric Cars; Publications Office of the European Union: Luxembourg, 2015; ISBN 978-92-79-51894-2. [CrossRef]

46. Von Der Leyen, U. A Union that Strives for More My Agenda for Europe, Political Guidelines For The Next European Commission 2019-2024. Available online: https://ec.europa.eu/commission/sites/beta-political/ files/political-guidelines-next-commission_en.pdf (accessed on 10 March 2020).

47. Harrison, G.; Gómez Vilchez, J.J.; Thiel, C. Industry strategies for the promotion of E-mobility under alternative policy and economic scenarios. Eur. Transp. Res. Rev. 2018, 10, 19. [CrossRef]

48. European Commission Weekly Oil Bulletin. Available online: https://ec.europa.eu/energy/en/data-analysis/ weekly-oil-bulletin (accessed on 24 July 2019).

49. Eurostat Electricity prices, tables nrg_pc_204 and nrg_pc_204_h. Available online: https://ec.europa.eu/ eurostat/data/database (accessed on 24 July 2019).

50. Gómez Vilchez, J.; Harrison, G.; Kelleher, L.; Smyth, A.; Thiel, C.; Lu, H.; Rohr, C. Quantifying the Factors Influencing People's Car Type Choices in Europe: Results of a Stated Preference Survey; Publications Office of the European Union: Luxembourg, 2017; ISBN 978-92-79-77201-6. [CrossRef]

51. Moraga, G.; Huysveld, S.; Mathieux, F.; Blengini, G.A.; Alaerts, L.; Van Acker, K.; de Meester, S.; Dewulf, J. Circular economy indicators: What do they measure? Resour. Conserv. Recycl. 2019, 146, 452-461. [CrossRef] [PubMed]

52. European Commission Commission action plan on financing sustainable growth. Available online: https: //ec.europa.eu/info/publications/180308-action-plan-sustainable-growth_en (accessed on 10 March 2020).

53. Kumar, R.R.; Alok, K. Adoption of electric vehicle: A literature review and prospects for sustainability. J. Clean. Prod. 2020, 253, 119911. [CrossRef]

54. IEA. Global EV Outlook 2019; IEA: Paris, France, 2019.

55. Jayakumar, A.; Chalmers, A.; Lie, T.T. Review of prospects for adoption of fuel cell electric vehicles in New Zealand. IET Electr. Syst. Transp. 2017, 7, 259-266. [CrossRef]

56. Alonso Raposo, M.; Ciuffo, B.; Alves Dies, P.; Ardente, F.; Aurambout, J.-P.; Baldini, G.; Baranzelli, C.; Blagoeva, D.; Bobba, S.; Braun, R.; et al. The Future of Road Transport-Implications of Automated, Connected, Low-Carbon and Shared Mobility; Publications Office of the European Union: Luxembourg, 2019; ISBN 978-92-76-14318-5. [CrossRef]

57. Alibakhshikenari, M.; Virdee, B.S.; Ali, A.; Limiti, E. A novel monofilar-Archimedean metamaterial inspired leaky-wave antenna for scanning application for passive radar systems. Microw. Opt. Technol. Lett. 2018, 60, 2055-2060. [CrossRef]

58. Trentadue, G.; Pinto, R.; Salvetti, M.; Zanni, M.; Pliakostathis, K.; Scholz, H.; Martini, G. Assessment of Low-Frequency Magnetic Fields Emitted by DC Fast Charging Columns. Bioelectromagnetics 2020, bem.22254. [CrossRef]

59. Pliakostathis, K.; Zanni, M.; Trentadue, G.; Scholz, H. Vehicle Electromagnetic Emissions: Challenges and Considerations. In Proceedings of the 2019 International Symposium on Electromagnetic Compatibility_EMC EUROPE, Barcelona, Spain, 2-6 September 2019 2019; pp. 1106-1111. [CrossRef]

(C) 2020 by the authors. Licensee MDPI, Basel, Switzerland. This article is an open access article distributed under the terms and conditions of the Creative Commons Attribution (CC BY) license (http://creativecommons.org/licenses/by/4.0/). 